\title{
REVIEW
}

\section{Optimising preoperative diagnosis in phyllodes tumour of the breast}

\author{
R K Jacklin, P F Ridgway, P Ziprin, V Healy, D Hadjiminas, A Darzi
}

J Clin Pathol 2006;59:454-459. doi: 10.1136/jap.2005.025866

The role of the pathologist in the preoperative diagnosis of phyllodes tumours of the breast is critical to appropriate surgical planning. However, reliable differentiation of phyllodes tumour from cellular fibroadenoma remains difficult. Preoperative diagnostic accuracy allows correct surgical treatment, avoiding the piffalls of reoperation because of inadequate excision, or surgical overtreatment. Specific clinical indices may arouse diagnostic suspicion but are unreliable for confirmation, as with current imaging modes. Fine needle aspiration cytology has a high false negative rate. Few studies have evaluated the role of core needle biopsy, but it may prove a useful adjunct. Both diagnostic and prognostic information may in future be gained from application of immunohistochemical and other techniques assessing the expression of proliferative markers including p53, $\mathrm{Ki}-67$, and others.

See end of article for authors' affiliations

Correspondence to:

Miss Rosamond K Jacklin, Department of Surgical Oncology and Technology, Imperial College, 10th Floor QEQM Building, St Mary's Hospital, Praed St, London W2 1NY, UK; r.jacklin@imperial.ac.uk

Accepted for publication 13 July 2005
$\mathrm{T}$ he recurring theme in phyllodes tumour is one of underdiagnosis by pathologists and undertreatment by surgeons. ${ }^{1}$ The role of the pathologist in the preoperative diagnosis of phyllodes tumour is crucial in minimising operative interventions for the patient. Accurate preoperative diagnosis allows correct surgical planning and avoidance of reoperation, either to achieve wider excision or for subsequent tumour recurrence. ${ }^{2}$ But has the diagnostic pathway changed in the 190 years since Chelius $^{3}$ first described this uncommon tumour?

Phyllodes tumour is a rare fibroepithelial neoplasm accounting for less than $1 \%$ of all breast tumours. ${ }^{4}$ It has a leaf-like architecture (fig 1) and infiltrating margins with marked stromal overgrowth and hypercellularity. ${ }^{5}$ The behaviour of phyllodes tumours ranges from benign and locally recurrent to malignant and metastatic. The accepted histological classification is into benign, borderline, and malignant subtypes $^{6-8}$ according to features such as tumour margins (pushing or infiltrative), stromal overgrowth, tumour necrosis, cellular atypia, and number of mitoses per high power field. However, histological grading has been shown correlate poorly with tumour behaviour, ${ }^{9} 10$ though the multiplicity of differing grading systems makes it difficult to be certain whether this effect is in part a result of disparities in approach.

Wide local excision (WLE) with at least a $1 \mathrm{~cm}$ margin is currently the treatment of choice for all grades of phyllodes tumour. ${ }^{7112}$ Indeed the margin required is subject to individual unit interpretations. This is in contrast to the treatment of fibroadenoma (the most frequent source of diagnostic difficulty), which may safely be managed by simple enucleation, and is increasingly being managed non-operatively when small. Thus if misdiagnosis as a fibroadenoma occurs, phyllodes tumour is either mistakenly treated conservatively by observation, or is inadequately resected. Residual phyllodes tumour at excision margins is a strong predictor of local tumour recurrence, ${ }^{12-15}$ and where excision has been inadequate, re-excision is advised. ${ }^{16}$ However, this carries significant psychological morbidity for the patient. ${ }^{17}$

Recent research interest has focused on the use of immunohistochemical markers, ${ }^{1}{ }^{18-30}$ flow cytometry, ${ }^{231-36}$ and other techniques ${ }^{37}{ }^{38}$ to elucidate the cellular basis of tumour behaviour and for the development of additional prognostic indicators.

\section{TRIPLE ASSESSMENT}

The introduction of triple assessment has standardised the diagnostic pathway for breast lumps, combining the results of clinical examination, radiological imaging, and fine needle aspiration cytology (FNAC) or core biopsy, or both, to achieve the highest levels of nonoperative diagnostic accuracy in breast disease. ${ }^{39}$ However, efficacy of the components of this process individually and in combination remains poor for the diagnosis of phyllodes tumour, ${ }^{40-42}$ as its features overlap with benign disease in all three categories.

\section{Clinical indices}

Phyllodes tumour usually presents with a clinically benign lump, which may be rapidly growing. Presentation may be precipitated by a sudden increase in size in a longstanding breast lesion. ${ }^{40}{ }^{43}$ Size at presentation is often larger than for fibroadenoma, although increased breast awareness and the impact of screening has resulted in a trend towards presentation at smaller tumour sizes. ${ }^{44}$ Overlying skin may show bluish discoloration and dilated veins, and pressure necrosis can occur. Prevalence is higher in Latin American white and Asian populations. ${ }^{45}$ The majority arise in women aged between 35 and 55 years $^{713}{ }^{43}$ (approximately 20 years later than fibroadenoma). While certain clinical features may raise the index of suspicion, phyllodes

Abbreviations: FNAC, fine needle aspiration cytology; SPF, S-phase fraction; WLE, wide local excision 


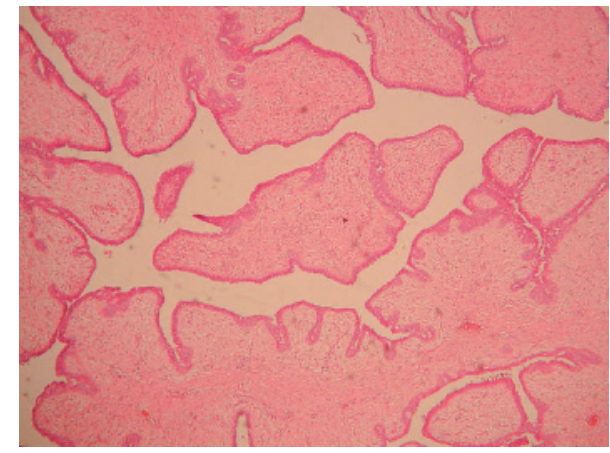

Figure 1 Photomicrograph of benign phyllodes tumour showing leaflike architecture (original magnification $\times 2$; H\&E stain).

tumour is not clinically distinguishable from fibroadenoma and other benign breast lesions. The diagnosis of phyllodes tumour should be considered and ruled out in the diagnostic pathway of larger fibroadenomata.

\section{Imaging}

Mammography and ultrasonography are the mainstays of routine imaging of breast lumps. Phyllodes tumour often mimics fibroadenoma at mammography, ${ }^{46}$ commonly appearing as a large, well circumscribed, oval or lobulated mass with rounded borders ${ }^{47}$ which may show a lucent halo or coarse microcalcifications. ${ }^{48}$ Ultrasonography typically shows an inhomogeneous, solid appearing mass ${ }^{47}$ with low level internal echoes, smooth walls, and good through transmission. ${ }^{49}$ Identification of a cyst within a solid lesion by ultrasound is highly suggestive of phyllodes tumour. ${ }^{46}$

The role of MRI has not been fully elucidated, but dynamic enhancement patterns may be helpful for the diagnosis of larger tumours $(>3 \mathrm{~cm}) .{ }^{50}$ Other experimental approaches

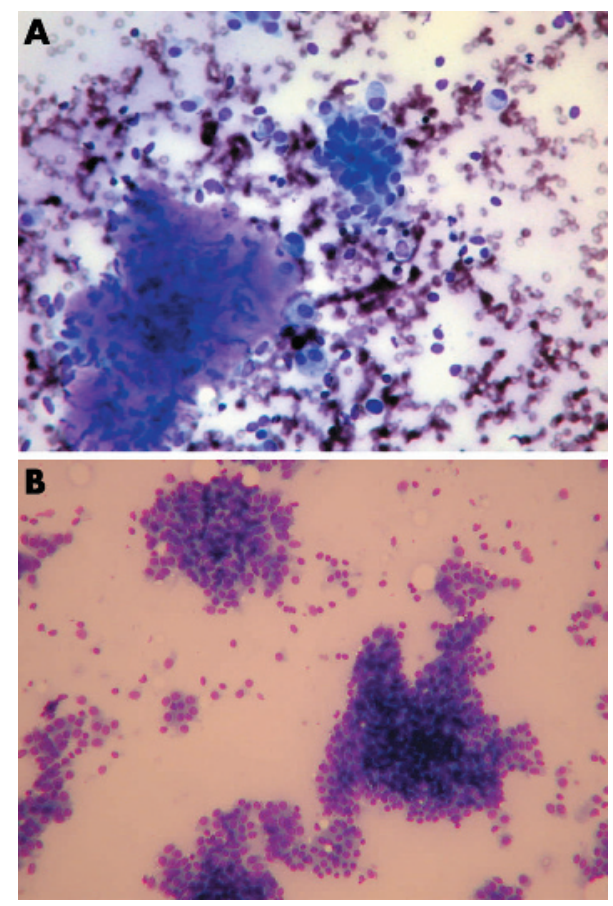

Figure 2 (A) Photomicrograph of fine needle aspiration cytology of the benign phyllodes tumour seen in fig 1 (original magnification $\times 20$, MGG stain). (B) Photomicrograph of fine needle aspiration cytology of cellular fibroadenoma (original magnification $\times 10$, MGG stain). Both panels show flat sheets of epithelial cells. include proton magnetic resonance spectroscopy ${ }^{51}$ and scintimammography. ${ }^{52} 53$ At present, however, many phyllodes tumours cannot be distinguished from fibroadenomas on radiological grounds, ${ }^{54}$ nor can benign and malignant variants be reliably differentiated, ${ }^{46} 495$ although one study found tumours larger than $3 \mathrm{~cm}$ in diameter are more likely to be malignant. ${ }^{56}$

\section{Fine needle aspiration cytology}

Cytological features of phyllodes tumour have been well described. Fibroadenomas and phyllodes tumours share a dimorphic pattern with both epithelial and stromal components. The key diagnostic features relate to the stroma, including the presence of hypercellular stromal fragments, well delineated borders to stromal fragments, stromal nuclear atypia, isolated stromal cells with bare nuclei, and blood vessels crossing the stromal fragments (fig 2). ${ }^{57-59}$

However, the value of FNAC in the diagnosis of phyllodes tumour remains controversial, with an overall accuracy of 63\%: in published reports of 156 FNAC examinations, there were 99 true positive results (table 1).

Sensitivity, specificity, and positive/negative predictive values as objective indices are not easily applicable in this context, for two reasons: first, study populations were selected from known cases with or without fibroadenoma controls (randomised prospective design being difficult owing to the rarity of the tumour). Second, where a statistical breakdown was presented, there was in all cases a significant indeterminate group. Where quantified, utility in these studies has been presented as a straightforward "diagnostic accuracy" percentage on the sample used-true phyllodes tumour definitively diagnosed on FNAC/total true phyllodes tumour $\times 100$. This varied from $32 \%$ to $77 \%$, though no fibroadenoma controls were used in the two studies reporting the highest accuracy. Some studies were blinded, though only one described in detail how this had been done. ${ }^{65}$ The degree of interobserver agreement was not quantified in any of the studies.

In addition to the presence of hypercellular stromal fragments, specific discriminating features included the percentage of long spindle nuclei in dispersed stromal cells $(>30 \% \text { found to be diagnostic of phyllodes tumour })^{64}$ and the size and shape of epithelial clusters $>1 \mathrm{~mm}$, elongated, and wavy/folded in phyllodes tumour, compared with smaller tubular or blunt-branching clusters in fibroadenoma. ${ }^{68}$

Accuracy of FNAC depends on an adequate and representative sample. ${ }^{69}$ Sampling problems can arise in phyllodes tumour because of the heterogeneous nature of these tumours, and the characteristic hypercellular fragments may be absent, especially if sampling has been done from relatively hypocellular, myxoid, or hyalinised areas of stroma. ${ }^{67}$ Even if the highest reported diagnostic accuracy results were widely reproducible, a quarter of phyllodes tumour would be undiagnosed by FNAC alone owing to large numbers of false negatives.

In three of the studies, tumour grading was attempted from cytological samples. The largest of these found good cytohistological correlation in $81 \%$. Of those inaccurately graded, nine of 11 were classified as being of lower (more benign) grade than the histological correlate. This effect was probably caused by sampling difficulties, with the matching histological slides showing only focal areas of stromal pleomorphism in an otherwise benign appearing tumour. ${ }^{44}$

\section{ROLE FOR CORE BIOPSY}

The introduction of automated core biopsy guns and refinement of image guided techniques for sampling nonpalpable breast lesions have resulted in the rapid acceptance of core needle biopsy in the non-operative diagnosis of breast 
Table 1 Medline listed peer reviewed reports since 1995 examining the role of fine needle aspiration cytology in diagnosis of phyllodes tumour

\begin{tabular}{|c|c|c|c|c|c|c|c|}
\hline Authors & Year & Focus of study & n (PT) & Controls & Blinding & $\begin{array}{l}\text { \% PT with } \\
\text { definite } \\
\text { diagnosis on } \\
\text { FNAC }\end{array}$ & Comments \\
\hline $\begin{array}{l}\text { Shabalova } \\
\text { et al }\end{array}$ & 1997 & $\begin{array}{l}\text { Diagnose benign } \\
\text { and borderline PT }\end{array}$ & 19 & $\begin{array}{l}\text { Yes (FA, fibrocystic } \\
\text { disease, and } \\
\text { carcinoma) }\end{array}$ & No & $32 \%$ & $\begin{array}{l}\text { Atypical changes in large proportion. Advise } \\
\text { care in cytopathological diagnosis if myxoid } \\
\text { stromal component }\end{array}$ \\
\hline Shabb et $a^{61}$ & 1997 & $\begin{array}{l}\text { Elucidate features } \\
\text { of PT }\end{array}$ & 8 & No & No & $\mathrm{N} / \mathrm{A}$ & $\begin{array}{l}\text { Discussion relates to distinguishing PT from FA. } \\
\text { Advise multiple aspirates and thin smears }\end{array}$ \\
\hline Deen et $a^{62}$ & 1999 & $\begin{array}{l}\text { Distinguish FA } \\
\text { and PT }\end{array}$ & 19 & Yes (FA) & No & $N / A$ & $\begin{array}{l}\text { Overlapping spectrum. Suggest intermediate } \\
\text { group of uncertain malignant potential }\end{array}$ \\
\hline Bhattarai et $\left.a\right|^{163}$ & 2000 & $\begin{array}{l}\text { Determine PT } \\
\text { subtypes }\end{array}$ & 80 & No & Yes & $71.3 \%$ & $\begin{array}{l}\text { Good cytohistological correlation in } 81 \% \text {. Advise } \\
\text { multiple site aspiration }\end{array}$ \\
\hline $\begin{array}{l}\text { Krishnamurthy } \\
\text { et al }\end{array}$ & 2000 & $\begin{array}{l}\text { Distinguish FA } \\
\text { and PT }\end{array}$ & 12 & Yes (FA) & No & $33.3 \%$ & $\begin{array}{l}\text { Long spindle nuclei comprising } \geqslant 30 \% \text { of } \\
\text { dispersed stromal cells diagnostic of phyllodes } \\
\text { tumour }(10-30 \%=\text { indeterminate) }\end{array}$ \\
\hline Scolyer et a ${ }^{165}$ & 2001 & $\begin{array}{l}\text { Distinguish FA } \\
\text { and PT }\end{array}$ & 8 & Yes (FA) & Yes & $62.5 \%$ & $\begin{array}{l}\text { Hypercellular stromal fragments most useful } \\
\text { feature - presence should raise possibility of PT }\end{array}$ \\
\hline Badhe et $a l^{66}$ & 2002 & $\begin{array}{l}\text { Distinguish FA and } \\
\text { PT and determine } \\
\text { subtypes }\end{array}$ & 9 & Yes (FA) & Yes & $77 \%$ & $\begin{array}{l}\text { Semiquantitative team approach improved } \\
\text { diagnosis of FA }\end{array}$ \\
\hline Jayaram et a ${ }^{67}$ & 2002 & $\begin{array}{l}\text { Diagnose PT and } \\
\text { determine subtypes }\end{array}$ & 28 & No & No & $71.4 \%$ & $\begin{array}{l}\text { Criteria for diagnosis of benign PT = at least two } \\
\text { of large stromal fragments, hypercellular stromal } \\
\text { fragments, and moderate to large numbers of } \\
\text { dissociated stromal cells }\end{array}$ \\
\hline Shimizu et $a^{68}$ & 2002 & $\begin{array}{l}\text { Distinguish FA } \\
\text { and benign PT }\end{array}$ & 18 & Yes (FA) & No & N/A & $\begin{array}{l}\text { Size and shape of epithelial clusters provide } \\
\text { additional clues (longer than } 1 \mathrm{~mm} \text {, wavy or } \\
\text { folded in phyllodes tumour) }\end{array}$ \\
\hline Totals & & & 201 & & & $99 / 156=63 \%$ & Indeterminate results excluded \\
\hline
\end{tabular}

FA, fibroadenoma; FNAC, fine needle aspiration cytology; PT, phylloides tumour.

lumps. Local protocols determine its usage in conjunction with FNAC. For example, at St Mary's Hospital, Paddington, all patients undergoing FNAC of a breast lump also have a core biopsy.

The microscopic appearance of phyllodes tumour is similar to that of intracanalicular fibroadenoma, with an elongated ductal component and epithelium lined papillary protrusions of stromal connective tissue which produce the leaf-like gross appearance from which the tumour's name is derived. ${ }^{5}$

Phyllodes tumour may usually be differentiated histologically from fibroadenoma by its increased stromal cellularity (fig 3) and mitotic activity. However, benign phyllodes tumour by definition lacks marked atypia and excess mitotic activity in its stromal component, and juvenile fibroadenoma may also have cellular stroma, presenting a source of increased diagnostic difficulty. Diagnosis relies on recognition of the exaggerated intracanalicular growth pattern in phyllodes tumour. In addition, the stromal proliferation in juvenile fibroadenoma tends to be relatively uniform, whereas in phyllodes tumour it is often (though not always) more prominent in the periductal areas. ${ }^{5}$ The stromal

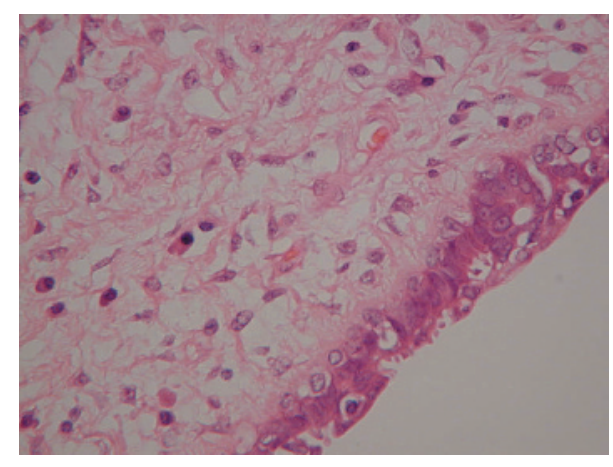

Figure 3 Photomicrograph of benign phyllodes tumour showing increased cellularity (original magnification $\times 40$; H\&E stain). cellularity in phyllodes tumour may be heterogeneous. Foci indistinguishable from fibroadenoma may lie adjacent to more cellular regions. ${ }^{70}$ This carries potential for sampling error, and where core needle biopsy is undertaken, sampling should be thorough to minimise this risk.

The guidelines recommend that phyllodes tumour should be designated $\mathrm{B} 3$ on core needle biopsy reporting, ${ }^{69}$ and in the rare cases where it cannot be differentiated from fibroadenoma it should be called a "fibroepithelial tumour" to avoid underdiagnosis of phyllodes tumour, with correlation to clinical and imaging findings. This should ideally occur in the context of a multidisciplinary meeting.

Review of the published reports showed very few articles specifically addressing the efficacy of core needle biopsy for preoperative diagnosis of phyllodes tumour. In the largest series of 57 biopsies in which phyllodes tumour was suspected or could not be ruled out, a favoured diagnosis was given in 48 cases. The biopsies were considered equivocal in the remaining nine. Of the 23 core biopsies where phyllodes tumour was favoured, 19 were confirmed on excisional biopsy. More importantly, of the 25 where fibroadenoma was favoured, only two were in fact phyllodes tumour and these were both histologically benign. The authors argue that this high accuracy is perhaps its greatest benefit, as patients with a core biopsy favouring fibroadenoma can avoid surgery and be managed with close follow up. ${ }^{44}$ In a separate study, core needle biopsy was undertaken in 12 patients with palpable breast lesions in whom FNA cytology had not produced a definitive diagnosis. Among these, one had a presumed fibroadenoma on FNAC, but core biopsy definitively confirmed benign phyllodes tumour. The authors concluded that this was one of the circumstances in which supplemental core biopsy was especially useful. ${ }^{71}$

Although core needle biopsy is not exempt from the sampling issues previously described, its selective use represents an attractive option for improving non-operative diagnostic yield in phyllodes tumour. In addition, histological tumour grading may be attempted preoperatively on the core 
biopsy sample. Attempts have been made to define sets of criteria based on histological features that will correlate with tumour behaviour. The most well known are those proposed by Azzopardi et al, ${ }^{6}$ Pietruska and Barnes, ${ }^{8}$ and Norris and Taylor. ${ }^{72}$ These subclassify phyllodes tumour into benign, borderline/intermediate, and malignant subtypes according to features such as tumour margins (pushing or infiltrative), stromal overgrowth, tumour necrosis, cellular atypia, and number of mitoses per high power field (fig 4). These multiple different classification systems have arisen because correlation of histological tumour grade to clinical course has been considered problematic. ${ }^{10}$ In a careful review of all published series of histological findings on excised tumours, Barth ${ }^{17}$ argued that histologic findings can be used according to existing criteria to identify a subgroup of patients whose tumours are benign in so far as they are very unlikely to metastasise and prove lethal, but all groups have the propensity for local recurrence. Infiltrating tumour contour, increasing stromal atypia, and high mitotic count are associated with worse clinical outcome at the malignant end of the spectrum. ${ }^{8}{ }^{72}$ Rates of recurrence after wide local excision are, however, higher (36\% in the malignant and $29 \%$ in the intermediate groups, as compared with $8 \%$ of benign tumours) This raises the question as to whether WLE is adequate for these groups, though even with data pooled from all available studies, the numbers remain small ( $\mathrm{n}=45$ for the malignant phyllodes tumour). ${ }^{17}$ If evidence accumulates that malignant phyllodes tumour warrants more radical surgery, preoperative grading using a core biopsy sample will assume greater importance.

\section{ROLE OF MARKERS OF CELL PROLIFERATION}

Methods of determining proliferative activity in tumours have been developed to assist with tumour grading for various types of malignancy, including breast carcinoma. Techniques to determine cell division kinetics have been applied to phyllodes tumour for correlation with both histological grading and clinical outcome. These have included flow cytometric determination of the S-Phase fraction (SPF)/DNA ploidy, p53 expression, and MIB-1 index.

Results of flow cytometric analysis have been mixed. One study showed a good correlation of both SPF and ploidy with histological grade, ${ }^{73}$ but this has not been replicated in other studies. ${ }^{32} 33{ }^{36}$ DNA content has been shown in one study to predict clinical outcome, ${ }^{2}$ with aneuploid tumours following a more aggressive course, ${ }^{31}$ though other studies found that the clinical outcome was significantly correlated with $\mathrm{SPF}^{35}$ but not ploidy. ${ }^{36}$ Cytogenetically, phyllodes tumour shows karyotype abnormalities, mostly chromosome gains. ${ }^{74}$ As such changes and the implications of their role in histogenesis become more clearly understood, they may in future be

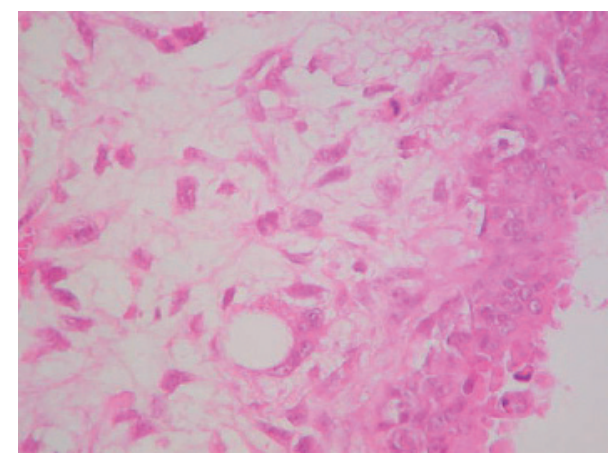

Figure 4 Photomicrograph of malignant phyllodes tumour showing increased cellularity and mitoses (original magnification $\times 20$; $\mathrm{H} \& \mathrm{E}$ stain). useful both for diagnosis of difficult cases and for tumour grading.

P53 expression in phyllodes tumour is associated with histological features of malignancy, ${ }^{18} 2360$ 75-77 with increasing positivity documented in tumours that have shown progression from benign to malignant phenotypes indicating a role in pathogenesis. ${ }^{19}{ }^{25}$ One study showed it to be an independent predictor of disease-free survival, ${ }^{35}$ but others have shown it cannot predict recurrence. ${ }^{25} 7879$ There were no studies indicating utility of p53 expression for distinguishing benign phyllodes tumour and fibroadenoma.

MIB- 1 is a monoclonal antibody with epitope selectivity to the human Ki-67 protein, which is present during all active phases of the cell cycle but is absent from resting cells. This makes it an excellent marker for determining the growth fraction of a given cell population. ${ }^{80}$ Several studies have shown a positive correlation between MIB-1 index and histological grade. One of the larger one has demonstrated that Ki-67 expression (as measured by MIB- 1 index) is inversely correlated with overall survival. ${ }^{35}$

Use of MIB-1 index for differentiating between benign phyllodes tumours and fibroadenomas has also yielded conflicting results. A previous study from our group showed a highly significant difference in MIB-1 indices between the stromal component of phyllodes tumour and fibroadenoma $(\mathrm{p}=<0.001),{ }^{1}$ confirming the findings of Kocova et $a l^{81}$ and supporting its potential use in reducing diagnostic uncertainty in difficult cases. Two studies have failed to find a significant difference between these two groups. ${ }^{22} 82$ However, all four studies have involved relatively small numbers, and differences in histological criteria used to define the benign group provide an additional confounding factor. There is as yet no published work to test the hypothesis that diagnostic sensitivity and specificity of core biopsy in this context may be enhanced by adjunctive use of MIB-1 index, nor has an appropriate cut off value been clearly determined.

\section{GUIDELINES FOR PREOPERATIVE DIAGNOSIS}

The preoperative diagnosis of phyllodes tumour of the breast continues to challenge pathologist and surgeon alike. The existing literature has been reviewed in the light of this challenge and it is concluded that core biopsy is potentially the most useful investigation for the preoperative diagnosis of phyllodes tumour. It is cost-effective and minimally invasive compared with excision biopsy. ${ }^{71}$ Existing data justify its use when the clinical suspicion of phyllodes tumour is raised, though sampling issues remain a concern.

We propose the Paddington Clinicopathologic Suspicion Score (Box 1). This outlines criteria to assist in the selection of patients for core biopsy, for use in conjunction with existing local protocols. We suggest that the presence of any two features mandates preoperative core biopsy. The aim of developing the score is to crystallise the features that clinicians already appraise intuitively, with the goal of improving rates of preoperative diagnosis. A prospective evaluation of its use is planned.

Although FNAC findings are included in the score, they need not necessarily form part of the diagnostic pathway. Where clinico-radiological features of phyllodes tumour are present, core biopsy is preferred owing to the high rates of false negative/indeterminate findings for FNAC.

The use of immunohistochemical or other adjunctive tests should be decided on a case to case basis. We look forward to the validation of more sophisticated immunochemical and other techniques to reduce diagnostic uncertainty in the more difficult cases, and the deeper understanding of the histogenesis of this uncommon tumour that will emerge as a result. 


\section{Box 1: Criteria for preoperative core biopsy}

The Paddington Clinicopathologic Suspicion Score Clinical findings

- Sudden increase in size in a longstanding breast lesion

- Apparent fibroadenoma $>3 \mathrm{~cm}$ diameter or in patient $>35$ years

Imaging findings

- Rounded borders/lobulated appearance at mammography

- Attenuation or cystic areas within a solid mass on ultrasonography

\section{FNAC findings}

- Presence of hypercellular stromal fragments

- Indeterminate features

\section{ANY 2 features mandate core biopsy}

\section{Take home message}

Consider all fibroadenomas as possible phyllodes tumours until proven otherwise, with core biopsy done preoperatively if the index of suspicion is raised

\section{Authors' affiliations}

P F Ridgway, P Ziprin, A Darzi, Department of Surgical Oncology and Technology, Imperial College, London, UK

V Healy, Department of Pathology, Imperial College, London, UK D Hadjiminas, Department of Surgery, St Mary's Hospital, Praed St, London, UK

\section{REFERENCES}

1 Ridgway PF, Jacklin RK, Ziprin P, et al. Perioperative diagnosis of cystosarcoma phyllodes of the breast may be enhanced by MIB-1 index. J Surg Res 2004; 122:83-8

2 El-Naggar AK, Mackay B, Sneige N, et al. Stromal neoplasms of the breast: a comparative flow cytometric study. J Surg Oncol 1990;44:151-6.

3 Chelius M. Neue Jahrbucher der Teutschen Medicin and Chirurgie. Heidelberg: Naegele und Puchelt, 1827:517-21

4 Rowell MD, Perry RR, Hsiu JG, et al. Phyllodes tumors. Am J Surg 1993; 165:376-9.

5 Rosen PP, Oberman HA. Tumors of the mammary gland. Washington, DC: Armed Forces Institute of Pathology, 1993:107-13.

6 Azzopardi JG, Ahmed A, Millis RR. Problems in breast pathology. Major Probl Pathol 1979:11:346-64.

7 Salvadori B, Cusumano F, Del Bo R, et al. Surgical treatment of phyllodes tumors of the breast. Cancer 1989;63:2532-6.

8 Pietruszka M, Barnes L. Cystosarcoma phyllodes: a clinicopathologic analysis of 42 cases. Cancer 1978:41:1974-83.

9 Kok KY, Telesinghe PU, Yapp SK. Treatment and outcome of cystosarcoma phyllodes in Brunei: a 13-year experience. J R Coll Surg Edinb 2001;46:198-201.

10 Kario K, Maeda S, Mizuno Y, et al. Phyllodes tumor of the breast: a clinicopathologic study of 34 cases. J Surg Oncol 1990;45:46-51.

11 Chaney AW, Pollack A, Marsha D, et al. Primary treatment of cystosarcoma phyllodes of the breast. Cancer 2000;89:1502-10.

12 Kapiris I, Nasiri N, A'Hern R, et al. Outcome and predictive factors of local recurrence and distant metastases following primary surgical treatment of high-grade malignant phyllodes tumours of the breast. Eur J Surg Oncol 2001;27:723-30

13 Cohn-Cedermark G, Rutqvist LE, Rosendahl I, et al. Prognostic factors in cystosarcoma phyllodes. A clinicopathologic study of 77 patients. Cancer $1991 ; 68: 2017-22$

14 Moffat CJ, Pinder SE, Dixon AR, et al. Phyllodes tumours of the breast: a clinicopathological review of thirty-two cases. Histopathology 1995;27:205-18.

15 de Roos WK, Kaye P, Dent DM. Factors leading to local recurrence or death after surgical resection of phyllodes tumours of the breast. Br J Surg $1999 ; 86: 396-9$
16 Mangi A, Smith B, Gadd M, et al. Surgical management of phyllodes tumours. Arch Surg 1999;134:487-91.

17 Barth RJ. Histologic features predict local recurrence after breast conserving therapy of phyllodes tumors. Breast Cancer Res Treat 1999;57:291-5.

18 Chan YJ, Chen BF, Chang CL, et al. Expression of p53 protein and Ki-67 antigen in phyllodes tumor of the breast. J Chin Med Assoc 2004;67:3-8.

19 Gatalica Z, Finkelstein S, Lucio E, et al. p53 protein expression and gene mutation in phyllodes tumors of the breast. Pathol Res Pract 2001;197:183-7.

20 Chu JS. Prognostic factors in phyllodes tumor of the breast: are immunohistochemical biomarkers useful? (comment). J Chin Med Assoc 2004:67:1-2.

21 Aranda FI, Laforga JB, Lopez Jl. Phyllodes tumor of the breast. An immunohistochemical study of 28 cases with special attention to the role of myofibroblasts. Pathol Res Pract 1994:190:474-81.

22 Barwijuk-Machala M, Musiatowicz B, Cylwik J, et al. AgNOR, Ki-67 and PCNA expression in fibroepithelial tumours of the breast in correlation with morphological features. Folia Morphol (Warsz) 2004;63:133-5.

23 Dacic S, Kounelis S, Kouri $E$, et al. Immunohistochemical profile of cystosarcoma phyllodes of the breast: a study of 23 cases. Breast J 2002;8:376-81.

24 Kuenen-Boumeester V, Henzen-Logmans SC, Timmermans MM, et al. Altered expression of p53 and its regulated proteins in phyllodes tumours of the breast. J Pathol 1999:189:169-75.

25 Shpitz B, Bomstein Y, Sternberg A, et al. Immunoreactivity of p53, Ki-67, and c-erbB-2 in phyllodes tumors of the breast in correlation with clinical and morphologic features. J Surg Oncol 2002;79:86-92.

26 Suo Z, Nesland JM. Phyllodes tumor of the breast: EGFR family expression and relation to clinicopathological features. Ultrastruct Pathol 2000;24:371-81

27 Umekita Y, Yoshida H. Immunohistochemical study of MIB1 expression in phyllodes tumor and fibroadenoma. Pathol Int 1999;49:807-10.

28 Umekita $\mathrm{Y}$, Yoshida $\mathrm{H}$. Immunohistochemical study of hormone receptor and hormone-regulated protein expression in phyllodes tumour: comparison with fibroadenoma. Virchows Arch 1998;433:311-14

29 Feakins RM, Wells CA, Young KA, et al. Platelet-derived growth factor expression in phyllodes tumors and fibroadenomas of the breast. Hum Patho 2000;31:1214-22.

30 Rao BR, Meyer JS. Progesterone receptor in cystosarcoma phyllodes. Arch Surg 1977;1 12:620-2.

31 el-Naggar AK, Ro JY, McLemore D, et al. DNA content and proliferative activity of cystosarcoma phyllodes of the breast. Potential prognostic significance. Am J Clin Pathol 1990;93:480-5.

32 Layfield LJ, Hart J, Neuwirth $\mathrm{H}$, et al. Relation between DNA ploidy and the clinical behavior of phyllodes tumors. Cancer 1989;64:1486-9.

33 Grimes MM. Cystosarcoma phyllodes of the breast: histologic features, flow cytometric analysis, and clinical correlations. Mod Pathol 1992;5:232-9.

34 Keelan PA, Myers JL, Wold LE, et al. Phyllodes tumor: clinicopathologic review of 60 patients and flow cytometric analysis in 30 patients. Hum Pathol 1992;23:1048-54

35 Niezabitowski A, Lackowska B, Rys J, et al. Prognostic evaluation of proliferative activity and DNA content in the phyllodes tumor of the breast: immunohistochemical and flow cytometric study of 118 cases. Breast Cancer Res Treat 2001;65:77-85

36 Palko MJ, Wang SE, Shackney SE, et al. Flow cytometric S fraction as a predictor of clinical outcome in cystosarcoma phyllodes. Arch Pathol Lab Med 1990; 114:949-52

37 Dal Cin P, Moreman P, De Wever I, et al. Is i (1)(q10) a chromosome marker in phyllodes tumor of the breast?(comment). Cancer Genet Cytogenet 1995:83:174-5.

38 Kasami M, Vnencak-Jones CL, Manning S, et al. Monoclonality in fibroadenomas with complex histology and phyllodal features. Breast Cancer Res Treat 1998;50:185-91.

39 Lamb J, Anderson TJ, Dixon MJ, et al. Role of fine needle aspiration cytology in breast cancer screening. J Clin Pathol 1987:40:705-9.

40 Chua CL, Thomas A, $\mathrm{Ng} \mathrm{BK}$. Cystosarcoma phyllodes: a review of surgical options. Surgery 1989;105:141-7.

41 Stebbing JF, Nash AG. Diagnosis and management of phyllodes tumour of the breast: experience of 33 cases at a specialist centre. Ann R Coll Surg Engl 1995:77:181-4.

42 Umpleby HC, Moore I, Royle GT, et al. An evaluation of the preoperative diagnosis and management of cystosarcoma phyllodes. Ann R Coll Surg Engl 1989;71:285-8.

43 Reinfuss M, Mitus J, Duda K, et al. The treatment and prognosis of patients with phyllodes tumor of the breast: an analysis of 170 cases. Cancer 1996;77:910-16.

44 Komenaka IK, El-Tamer M, Pile-Spellman E, et al. Core needle biopsy as a diagnostic tool to differentiate phyllodes tumor from fibroadenoma. Arch Surg 2003; 138:987-90.

45 Bernstein L, Deapen D, Ross RK. The descriptive epidemiology of malignant cystosarcoma phyllodes tumors of the breast. Cancer 1993;71:3020-4.

46 Jorge Blanco A, Vargas Serrano B, Rodriguez Romero R, et al. Phyllodes tumors of the breast. Eur Radiol 1999;9:356-60.

47 Feder JM, de Paredes ES, Hogge JP, et al. Unusual breast lesions: radiologicpathologic correlation. Radiographics 1999;19:11-26.

48 Cosmacini P, Veronesi P, Zurrida S, et al. Mammography in the diagnosis of phyllodes tumors of the breast. Analysis of 99 cases. Radiol Med (Torino) 1991;82:52-5.

49 Cole-Beuglet $C$, Soriano R, Kurtz AB, et al. Ultrasound, x-ray mammography, and histopathology of cystosarcoma phylloides. Radiology 1983;146:481-6.

50 Kinoshita T, Fukutomi T, Kubochi K. Magnetic resonance imaging of benign phyllodes tumors of the breast. Breast J 2004;10:232-6. 
51 Tse GMK, Cheung HS, Pang L-M, et al. Characterization of lesions of the breast with proton MR spectroscopy: comparison of carcinomas, benign lesions, and phyllodes tumors. Am J Roentgenol 2003;181:1267-72

52 Katayama N, Inoue Y, Ichikawa T, et al. Increased activity in benign phyllodes tumor on Tc-99m MDP scintimammography. Clin Nucl Med 2000;25:551-2.

53 Ohta H, Komibuchi T, Nishio T, et al. Technetium-99m-sestamibi scintimammography of benign and malignant phyllodes tumors. Ann Nucl Med 1997;11:37-9.

54 Page JE, Williams JE. The radiological features of phylloides tumour of the breast with clinico-pathological correlation. Clin Radiol 1991;44:8-12.

55 Buchberger W, Strasser K, Heim K, et al. Phylloides tumor: findings on mammography, sonography, and aspiration cytology in 10 cases. Am J Roentgenol 1991;157:715-19.

56 Liberman L, Bonaccio E, Hamele-Bena D, et al. Benign and malignant phyllodes tumors: mammographic and sonographic findings. Radiology 1996;198:121-4

57 Chhieng DC, Cangiarella JF, Waisman J, et al. Fine-needle aspiration cytology of spindle cell lesions of the breast. Cancer 1999;87:359-71.

58 Stanley MW, Tani EM, Rutqvist LE, et al. Cystosarcoma phyllodes of the breast: a cytologic and clinicopathologic study of 23 cases. Diagn Cytopathol 1989;5:29-34

59 Simi U, Moretti D, lacconi $P$, et al. Fine needle aspiration cytopathology of phyllodes tumor. Differential diagnosis with fibroadenoma. Acta Cytol 1988:32:63-6.

60 Shabalova IP, Chemeris GJ, Ermilova VD, et al. Phyllodes tumour: cytologic and histologic presentation of 22 cases, and immunohistochemical demonstration of p53. Cytopathology 1997;8:177-87.

61 Shabb NS. Phyllodes tumor. Fine needle aspiration cytology of eight cases. Acta Cytol 1997;41:321-6.

62 Deen SA, McKee GT, Kissin MW. Differential cytologic features of fibroepithelial lesions of the breast. Diagnostic Cytopathol 1999;20:53-6.

63 Bhattarai S, Kapila K, Verma K. Phyllodes tumor of the breast. A cytohistologic study of 80 cases. Acta Cytol 2000;44:790-6.

64 Krishnamurthy S, Ashfaq R, Shin HJ, et al. Distinction of phyllodes tumor from fibroadenoma: a reappraisal of an old problem. Cancer 2000;90:342-9.

65 Scolyer RA, McKenzie PR, Achmed D, et al. Can phyllodes tumours of the breast be distinguished from fibroadenomas using fine needle aspiration cytology? Pathology 2001;33:437-43.

66 Badhe BA, lyengar KR, Alva N. A study of fibroepithelial tumours of the breast. Indian J Cancer 2002;39:91-6.

67 Jayaram G, Sthaneshwar P. Fine-needle aspiration cytology of phyllodes tumors. Diagnostic Cytopathol 2002;26:222-7.
68 Shimizu K, Korematsu M. Phyllodes tumor of the breast. A cytomorphologic approach based on evaluation of epithelial cluster architecture. Acta Cytol 2002;46:332-6.

69 Ellis 1O, Humphreys S, Michell M, et al. Guidelines for non-operative diagnostic procedures and reporting in breast cancer screening. Sheffield: NHS Cancer Screening Programmes, 2001.

70 Rosen PP. Fibroepithelial neoplasms. In: Rosen's breast pathology, 2nd ed. Philadelphia: Lippincott-Raven, 1996:163-200.

71 Florentine BD, Cobb CJ, Frankel K, et al. Core needle biopsy. A useful adjunct to fine-needle aspiration in select patients with palpable breast lesions. Cancer 1997;81:33-9.

72 Norris HJ, Taylor HB. Relationship of histologic features to behavior of cystosarcoma phyllodes. Analysis of ninety-four cases. Cancer 1967;20:2090-9

73 Murad TM, Hines JR, Beal J, et al. Histopathological and clinical correlations of cystosarcoma phyllodes. Arch Pathol Lab Med 1988;112:752-6.

74 Barbosa ML, Ribeiro EMSF, Silva GF, et al. Cytogenetic findings in phyllodes tumor and fibroadenomas of the breast. Cancer Genet Cytogenet 2004; 154:156-9.

75 Erhan Y, Zekioglu O, Ersoy O, et al. p53 and $\mathrm{Ki}-67$ expression as prognostic factors in cystosarcoma phyllodes. Breast J 2002;8:38-44.

76 Feakins RM, Mulcahy HE, Nickols CD, et al. p53 expression in phyllodes tumours is associated with histological features of malignancy but does not predict outcome. Histopathology 1999;35:162-9.

77 Millar EK, Beretov J, Marr P, et al. Malignant phyllodes tumours of the breast display increased stromal p53 protein expression. Histopathology 1999:34:491-6.

$78 \mathrm{Kim} \mathrm{CJ}, \mathrm{Kim} \mathrm{WH}$. Patterns of $\mathrm{p} 53$ expression in phyllodes tumours of the breast-an immunohistochemical study. J Korean Med Sci 1993;8:325-8.

79 Kleer CG, Giordano TJ, Braun T, et al. Pathologic, immunohistochemical, and molecular features of benign and malignant phyllodes tumors of the breast. Mod Pathol 2001;14:185-90.

80 Scholzen T, Gerdes J. The Ki-67 protein: from the known and the unknown. J Cell Physiol 2000; 182:311-22.

81 Kocova L, Skalova A, Fakan F, et al. Phyllodes tumour of the breast: immunohistochemical study of 37 tumours using MIB1 antibody. Pathol Res Pract 1998; 194:97-104.

82 Kaya R, Pestereli HE, Erdogan G, et al. Proliferating activity in differential diagnosis of benign phyllodes tumor and cellular fibroadenomas: is it helpful? Pathol Oncol Res 2001;7:213-16. 